Bull. Chem. Soc. Ethiop. 2019, 33(3), 517-526.

ISSN 1011-3924

(c) 2019 Chemical Society of Ethiopia and The Authors

Printed in Ethiopia

DOI: https://dx.doi.org/10.4314/bcse.v33i3.12

\title{
CATALYTIC ACTIVITY OF NICKEL FERRITE NANOPARTICLES IN SYNTHESIS OF 4-ARYL BENZELIDENE-2-((5-FLUORO-1H-INDOL-1-YL)METHYL)OXAZOL- 5(4H)-ONE AND ITS EVALUTE THE BIOLOGICAL ACTIVITY
}

\author{
Tentu Nageswara Rao ${ }^{1 *}$, N. Krishna Rao ${ }^{2}$, Botsa Parvatamma ${ }^{3}$, \\ Velayudhan Kamala Devi ${ }^{4}$ and T. Manohra Naidu ${ }^{5}$ \\ ${ }^{1}$ School of Materials Science and Engineering, Changwon National University, Changwon, \\ Gyeongnam, 51140, Republic of Korea \\ ${ }^{2}$ Department of Chemistry, Krishna University, Machilipatnam, Andhrapradesh, India \\ ${ }^{3}$ Department of Organic Chemistry, Gayathri P.G Courses, Gotlam, Vizianagaram, AP, India \\ ${ }^{4}$ Department of Organic Chemistry, TSR \& TBK PG College, Visakhapatnam, AP, India \\ ${ }^{5}$ Department of Nuclear Physics, Andhra University, Visakhapatnam, Andhra Pradesh, India
}

(Received April 9, 2019; Revised August 1, 2019; Accepted August 20, 2019)

\begin{abstract}
Seven 4-arylbenzelidene-2-((5-fluoro-1H-indol-1-yl)methyl)oxazol-5(4H)-one derivatives were synthesized by the condensation of 2-(2-(5-fluoro- $1 \mathrm{H}-\mathrm{indol}-1-\mathrm{yl})$ acetoamide) acetic acid, substituted aromatic aldehydes with acetic anhydride and sodium acetate in the presence of $\mathrm{MgO} / \mathrm{Al}_{2} \mathrm{O}_{3}$ under reflux using nickel ferrite nanoparticles. Seven of the compounds are new derivatives. 2-(2-(5-fluoro-1H-indol-1-yl)acetoamide) acetic acid was obtained from 2-(5-fluoro-1H-indol-1-yl)acetyl chloride with lysine in the presence of $\mathrm{NaOH}$ and $\mathrm{HCl}$ in the ice cold solution. 2-(5-fluoro-1H-indol-1-yl)acetyl chloride can be prepared from 5-fluoro indole with chloroacetyl chloride in triethylamine and dichloromethane. The structures of the compounds were evaluated based on ${ }^{1} \mathrm{H}-\mathrm{NMR},{ }^{13} \mathrm{C}-\mathrm{NMR}$ and LC-MS and by elemental analysis. These compounds were screened by antioxidant as well as anti-microbial activity.
\end{abstract}

KEY WORDS: 2-(5-Fluoro-1H-indol-1-yl)acetyl chloride, 2-(2-(5-Fluoro-1H-indol-1-yl)acetoamide) acetic acid, 4-Aryl Benzelidene-2-((5-fluoro-1H-indol-1-yl)methyl)oxazol-5(4H)-one, Anti-oxidant, Anti-microbial activity, Nickel ferrite

\section{INTRODUCTION}

In recent decades, multicomponent reactions (MCRs) have been frequently used by synthetic chemists as an effective method to generate molecular diversity because of the high variability in reaction components and conditions. Moreover, these reactions have gained remarkable interest for chemists as an appropriate, atom economical, and time-saving procedure for the synthesis of various compounds with interesting properties. In recent years, many trends have emerged for the application of types of nanoparticles due to their potential features in various fields of modern organic synthesis and especially in MCRs. Nano-sized particles assist molecular interaction, thereby increasing the overall efficacy and affinity compared to biological molecules that interact with micro-sized particles [1]. Nickel ferrite nanoparticles were one of the most significant ferrites of the spinel. It has a completely reverse spinel structure displaying ferrimagnetism from magnetic moments of anti-parallel spinning between $\mathrm{Fe}^{3+}$ ions at tetrahedral locations and octahedral $\mathrm{Ni}^{2+}$ ions [2]. $\mathrm{NiFe}_{2} \mathrm{O}_{4}$ has a wide range of applications in many areas including biomedical applications, magnetic cooling, magnetic liquids, microwave absorber, etc [3]. The modern organic synthesis reactions in the presence of magnetic nanoparticles (MNPs) have many advantages such as high yield, short reaction times, low cost, selectivity, clean reaction profiles, and ecofriendly and environmentally benign conditions in comparison to the various strategies of the classical chemistry [4].

Active heterocyclic compounds are one of the significant topic of interest for the organic chemistry and medicinal chemistry which exhibit a number of pharmacological properties. A

*Corresponding author.tnrao80@changwon.ac.kr

This work is licensed under the Creative Commons Attribution 4.0 International License 
five and six membered heterocyclic compounds possesses nitrogen, sulphur, oxygen having occupied enormous significant in the field in the organic chemistry as well as medicinally chemistry (5). Oxazalones are five member heterocyclic compounds containing nitrogen and oxygen as hetero atoms. The C-2 and C-4 positions of oxazalones are responsible for their various biological activities such as analgesic, anti-inflammatory, antidepressant, anticancer, antimicrobial, antidiabetic and anti obesity. Oxazalones are heterocyclic compounds which perform an important role in the synthesis of several organic molecules including amino acids [6], amino alcohols, thiamine [7], amides, peptides [8] and polyfunctional compounds [9], Certain natural and synthetic oxazalones also including benzoxazolone [10, 11], derivatives possess important biological activities such as antimicrobial [12], anti-inflammatory [13], anticancer [14], anti-HIV [15] antiangiogenic [16], anticonvulsant, antitumor, antagonistic, sedative [17], and cardio tonic activity, These are used as synthons for the construction of various alkaloid skeletons, immunomodulator and biosensors [18].

Oxazalones exhibited promising photo physical and photochemical activities [19], so they are used in semiconductor devices such as electro photographic photoreceptors and in non-linear optical materials [20]. Oxazalones has cyclooxygenase-2 inhibitory property [21] and tyrosine's inhibitory property. 17 AG 50 Peptaibol, endothiopeptides, and 24-membered cyclic dipsipeptide were formed by "azirine/oxazalones" method which incorporate the Alb ( $\alpha$-aminoisobutyric) acid units for cyclization of the linear peptides [22-24]. The increases resistance against human pathogens that cause infections is one of the main topics areas of interest for the medicinal chemistry. The number of drug moiety was developed against bacterial infections. The present work done the oxazalones from 5-fluoro indole molecules and also examined the bioevaluation.

\section{EXPERIMENTAL}

The chemicals were procured from Sigma-Aldrich and E. Merck. Organic solvent used was absolute alcohol. Melting points of 4-arylbenzelidene-2-((5-fluoro-1H-indol-1-yl)methyl) oxazol-5(4H)-one were determined in open glass capillaries on a Mettler FP51 melting point apparatus and are uncorrected. The NMR spectra of selective compounds were recorded on a Bruker for $400{ }^{1} \mathrm{H}$ NMR spectra and $100 \mathrm{MHz}$ for ${ }^{13} \mathrm{C} \mathrm{NMR}$ spectra in $\mathrm{CDCl}_{3}$ solvent using TMS as internal standard. Chemical shifts $(\delta)$ are referred in terms of ppm and J-coupling constants are given in Hz. Abbreviations for multiplicity is as follows: s (singlet), $\mathrm{d}$ (doublet), $\mathrm{t}$ (triplet), q (quadruplet), $\mathrm{m}$ (multiplet). Electron impact and chemical ionization mode FAB+ mass spectra were recorded with a Shimadzu spectrometer. Elemental analysis was carried out on an Elementar Vario EL analyzer. Elemental analysis was obtained using Perkin Elmer (USA) 2400, series II CHN-analyser. Reactions were monitored by TLC, using silica gel as an adsorbent and ethyl acetate-hexane in different ratios as eluent.

\section{Preparation of nickel ferrite $\left(\mathrm{NiFe}_{2} \mathrm{O}_{4}\right)$ nanoparticles}

$\mathrm{NiFe}_{2} \mathrm{O}_{4}$ nanoparticles were prepared by co-precipitation method. $50 \mathrm{~mL}$ of $0.2 \mathrm{M}$ ferric chloride solution was taken into $250 \mathrm{~mL}$ glass beaker, and then $0.1 \mathrm{M}$ nickel chloride solution was added into a same beaker. This mixture was stirred at room temperature for 2 hours to form a homogeneous solution. The $\mathrm{pH}$ of the solution was constantly observed as the $3 \mathrm{M}$ sodium hydroxide solution was added drop wise. The reactants were consistently stirred using a magnetic stirrer until a $\mathrm{pH}$ level of $>12.5$ was achieved. A specified amount of oleic acid was added to the solution as the surfactant. The liquid precipitate was then brought to a reaction temperature of $80{ }^{\circ} \mathrm{C}$ and stirred for 1 hour. The product was cooled to room temperature and then washed twice with deionized water and ethanol to eliminate unwanted impurities and the residual surfactant from the prepared sample. Finally, the sample was centrifuged and then dried at $80{ }^{\circ} \mathrm{C}$. The acquired substance was then ground into a fine powder. 


\section{Characterization of $\mathrm{NiFe}_{2} \mathrm{O}_{4}$ nanoparticles}

The room temperature XRD profile of the synthesized $\mathrm{NiFe}_{2} \mathrm{O}_{4}$ nanoparticles was obtained to the crystal structure and phase purity of the sample the crystalline size was calculated from the XRD spectrum using "Debye Scherrer" equation. The Fourier transform infrared (FT-IR) spectrum was recorded on JASCO, FT/IR-6300 FT-IR spectrometer in $\mathrm{KBr}$ pellets. The characterization of $\mathrm{NiFe}_{2} \mathrm{O}_{4}$ nanoparticles by FESEM (TESCAN, CZ/MIRA I LMH) showed the development of nickel on iron matrix. The size of the particle was observed to be 6-7 $\mathrm{nm}$ by HRTEM (FEI, TECNAI G2 TF20-ST).

Synthesis of 2-(5-fluoro-1H-indol-1-yl) acetyl chloride (3)

5-Fluoroindole is dissolved in a base such as triethylamine and dichloromethane taken in a RB flask. The chloroacetyl chloride added to the above mixture with using dropping funnel by portion wise in fume cupboard in a cooling condition. The RB flask fitted on the magnetic stirrer under reflux condition and the reaction was monitored by TLC (6:4, n-hexane: ethylacetate). After all the reactants were consumed, the product poured in a ethylacetate and neutralizes with sodium bicarbonate solution. Final compound was recrystallized from ethanol. Corourless, yields of the compounds $77 \% .{ }^{1} \mathrm{H}$ NMR $\left(400 \mathrm{Mz}, \mathrm{CDCl}_{3}\right) \mathrm{ppm}$ : $7.632(\mathrm{~s}, 1 \mathrm{H}, \mathrm{Ar}-\mathrm{H})$, 7.541 (d, J = 8.8 Hz, Ar-H), 7.279 (d, J = 7.6 Hz, 1H, Ar-H), 7.117 (d, J = 9.2 Hz, Ar-H), 6.803 $(\mathrm{d}, \mathrm{J}=8.4 \mathrm{~Hz}, \mathrm{Ar}-\mathrm{H}), 1.935\left(\mathrm{~s}, 2 \mathrm{H},-\mathrm{CH}_{2}-\right) .{ }^{13} \mathrm{C} \mathrm{NMR}\left(100 \mathrm{Mz}, \mathrm{CDCl}_{3}\right) \mathrm{ppm}: 190.38,136.42$, $128.35,125.59,122.07,121.18,119.26,113.36,104.72,73.45$. LC-MS (m/z): $210.89(\mathrm{M}-\mathrm{H})$. Molecular formula: $\mathrm{C}_{10} \mathrm{H}_{7} \mathrm{ClFNO}$. Elemental analysis: calculated C-56.76, H-3.33, N-6.62. Obtained: C-56.72, H-3.32, N-6.69.

Synthesis of 2-(2-(5-fluoro-1H-indol-1-yl) acetoamide) acetic acid (6)

The glycine introduced in a $100 \mathrm{~mL}$ RB flask and dissolved in sodium hydroxide and few drops of conc. $\mathrm{HCl}$ with shaking vigorously in ice cold solution. The 2-(5-fluoro-1H-indol-1-yl) acetyl chloride added to above the mixture in RT condition. After completion of the reaction, the reaction mixture was taken with ethyl acetate and neutralized with base. The desired product can be obtained when recrystallized from ethanol. Corourless, yields of the compounds $75 \%$. ${ }^{1} \mathrm{H}$ NMR (400 MHz, $\mathrm{CDCl}_{3}$ ) ppm: 11.346 (s, 1H, $\left.-\mathrm{COOH}\right), 8.894$ (s, 1H, N-H, amide), 7.608 (s, 1H, Ar-H), $7.451(\mathrm{~d}, \mathrm{~J}=9.2 \mathrm{~Hz}, \mathrm{Ar}-\mathrm{H}), 7.392(\mathrm{~d}, \mathrm{~J}=8.4 \mathrm{~Hz}, \mathrm{Ar}-\mathrm{H}), 7.250$ (d, J = 8.4 Hz, Ar-H), $7.172(\mathrm{~d}, \mathrm{~J}=8.4 \mathrm{~Hz}, \mathrm{Ar}-\mathrm{H}), 1.882\left(\mathrm{~s}, 2 \mathrm{H},-\mathrm{CH}_{2}-\right), 1.486(\mathrm{~s}, 2 \mathrm{H}, \mathrm{Ar}-\mathrm{H}) .{ }^{13} \mathrm{C} \mathrm{NMR}(100 \mathrm{MHz}$, $\mathrm{CDCl}_{3}$ ) ppm: $171.65,166.72,136.08,128.36,127.94,125.82,121.48,119.77,112.49,103.81$, 42.23, 40.75. LC-MS (m/z): 250.08. Molecular formula: $\mathrm{C}_{12} \mathrm{H}_{11} \mathrm{FN}_{2} \mathrm{O}_{3}$. Elemental analysis: calculated: C-57.60, H-4.43, N-11.20. Obtained: C-57.55, H-4.41, N-11.28.

Preparation of derivatives of 4-benzylidine-2((5-fluoro-1H-indolyl-1-yl) methyl) oxazol-5(4H)one (8)

A mixture of 2-(2-(5-fluoro-1H-indol-1-yl)acetoamide) acetic acid with substituted aromatic aldehydes, acetic anhydride/sodium acetate taken in a $100 \mathrm{~mL}$ conical flask. The small amount of $\mathrm{MgO} / \mathrm{Al}_{2} \mathrm{O}_{3}$ added above the mixture under reaction condition. When $0.01 \mathrm{~mol}$ of nickel ferrite $\left(2.4 \mathrm{~g}\right.$ in $1000 \mathrm{~mL} 10 \%$ of aqueous $\mathrm{H}_{2} \mathrm{O}_{4}$ ) was added the above mixture. The reaction mixture carried on the magnetic stirrer and reflux condition. The reaction was check with TLC (6:4, n-hexane: ethylacetate) when the all the reactants were consumed and after completion of the reaction, the crude was poured in ice cold solution and addition with ethylacetate. The compound can be separated from crude by column chromatography (6:4, n-hexane:ethylacetate). 
4-Benzylidine-2((5-fluoro-1H-indolyl-1-yl)methyl)oxazol-5(4H)-one (6a). Corourless, yields 78\%. ${ }^{1} \mathrm{H}$ NMR (400 MHz, $\mathrm{CDCl}_{3}$ ) ppm: 7.608-7.392 (m, 7H, Ar-H), 7.321 (t, J = 8.0 Hz, 2H, Ar-H), $7.082(\mathrm{~d}, \mathrm{~J}=8.4 \mathrm{~Hz}, \mathrm{Ar}-\mathrm{H}), 6.665(\mathrm{~d}, \mathrm{~J}=8.4 \mathrm{~Hz}, 1 \mathrm{H}$ indole $), 2.089\left(\mathrm{~s}, 2 \mathrm{H}, \mathrm{CH}_{3}\right) .{ }^{13} \mathrm{C}$ NMR (100 MHz, $\mathrm{CDCl}_{3}$ ) ppm: 164.89, 161.72, 133.84, 129.03, 128.71, 128.33, 127.49, 126.68, $125.74,123.45,121.93,119.05,114.73,110.26$, 103.85, 57.42. LC-MS (m/z): 319.88 . Molecular formula: $\mathrm{C}_{19} \mathrm{H}_{13} \mathrm{FN}_{2} \mathrm{O}_{2}$. Elemental analysis: calculated: C-71.24, H-4.04, N-8.75. Obtained: C-71.20, H-4.03, N-8.81.

Benzylidine-2((5-fluoro-1H-indolyl-1-yl)methyl)-4-(4-hydroybenzylidine)oxazol-5(4H)-one (6b). Corourless, yield 80\%. ${ }^{1} \mathrm{H}$ NMR $\left(400 \mathrm{MHz}, \mathrm{CDCl}_{3}\right)$ ppm: $9.126(\mathrm{~s}, 1 \mathrm{H},-\mathrm{OH}), 7.536-7.281(\mathrm{~m}$, $5 \mathrm{H}, \mathrm{Ar}-\mathrm{H}), 7.156(\mathrm{~d}, \mathrm{~J}=8.4 \mathrm{~Hz}, \mathrm{Ar}-\mathrm{H}), 6.824(\mathrm{~d}, \mathrm{~J}=7.6 \mathrm{~Hz}, 1 \mathrm{H}, \mathrm{Ar}-\mathrm{H}), 5.856(\mathrm{~s}, 1 \mathrm{H},=\mathrm{C}-\mathrm{H})$, 1.923 (s, $\left.3 \mathrm{H}, \mathrm{CH}_{2}\right) .{ }^{13} \mathrm{C}$ NMR (100 MHz, $\mathrm{CDCl}_{3}$ ) ppm: 164.15, 161.36, 135.72, 129.64, 128.76, $128.19,127.38,125.47,123.62,121.09,120.48,119.77,111.38,108.42,57.05$. LC-MS (m/z): $335.52(\mathrm{M}-\mathrm{H})$. Molecular formula: $\mathrm{C}_{19} \mathrm{H}_{13} \mathrm{FN}_{2} \mathrm{O}_{3}$. Elemental analysis: calculated: C-67.85, H3.90, N-8.33. Obtained: C-67.80, H-3.88, N-8.39.

Benzylidine-2((5-fluoro-1H-indolyl-1-yl)methyl)-4-(4-methylbenzylidine)oxazol-5(4H)-one (6c). Pale yellow, yield 79\%. ${ }^{1} \mathrm{H}$ NMR (400 MHz, $\left.\mathrm{CDCl}_{3}\right)$ ppm: 7.741 (d, J = 8.4 Hz, Ar-H), 7.144 $(\mathrm{d}, \mathrm{J}=8.4 \mathrm{~Hz}, \mathrm{Ar}-\mathrm{H}), 6.925(\mathrm{~d}, \mathrm{~J}=8.4 \mathrm{~Hz}, 1 \mathrm{H}, \mathrm{Ar}-\mathrm{H}), 5.835(\mathrm{~s}, 1 \mathrm{H},=\mathrm{C}-\mathrm{H}), 2.175\left(\mathrm{~s}, 3 \mathrm{H},-\mathrm{CH}_{3}\right)$. ${ }^{13} \mathrm{C}$ NMR (100 MHz, $\mathrm{CDCl}_{3}$ ) ppm: 165.25, 162.84, 136.77, 130.06, 129.47, 128.68, 128.14, 127.33, 125.86, 123.45, 120.79, 118.92, 110.73, 107.08, 103.21, 54.32, 20.76. LC-MS (m/z): 335.38. Moleclar formula: $\mathrm{C}_{20} \mathrm{H}_{15} \mathrm{FN}_{2} \mathrm{O}_{2}$. Elemental analysis: calculated: $\mathrm{C}-71.85, \mathrm{H}-4.52, \mathrm{~N}-$ 8.38. Obtained: C-71.80, H-4.51, N-8.43.

Benzylidine-2((5-fluoro-1H-indolyl-1-yl)methyl)-4-(4-methoxybenzylidine)oxazol-5(4H)-one 6d). Pale yellow, yield 77\%. ${ }^{1} \mathrm{H}$ NMR $\left(400 \mathrm{MHz}, \mathrm{CDCl}_{3}\right)$ ppm: 7.631-7.335 (m, 7H, Ar H), $7.137(\mathrm{~d}, \mathrm{~J}=9.2 \mathrm{~Hz}), 6.8745(\mathrm{~d}, \mathrm{~J}=7.6 \mathrm{~Hz}, 1 \mathrm{H}, \mathrm{Ar}-\mathrm{H}), 5.524(\mathrm{~s}, 1 \mathrm{H},=\mathrm{C}-\mathrm{H}), 2.163(\mathrm{~s}, 2 \mathrm{H}$, $\left.\mathrm{CH}_{2}\right) .{ }^{13} \mathrm{C}$ NMR $\left(100 \mathrm{MHz}, \mathrm{CDCl}_{3}\right)$ ppm: 165.73, 160.62, 136.46, 129.64, 128.72, 128.06, 127.88, 127.34, 126.92, 125.44, 124.38, 120.02, 118.28, 115.09, 112.36, 102.93, 57.49, 53.12. LC-MS (m/z): $349.76(\mathrm{M}-\mathrm{H})$. Molecular formula: $\mathrm{C}_{20} \mathrm{H}_{15} \mathrm{FN}_{2} \mathrm{O}_{3}$. Elemental analysis: calculated: C-68.57, H-4.32, N-8.00. Obtained: C-68.53, H-4.30, and N-8.08.

4-(4-Bromobenzylidine)-2((5-fluoro-1H-indolyl-1-yl)methyl)-oxazol-5(4H)-one (6e). Red colour, yield 77\%. ${ }^{1} \mathrm{H}$ NMR $400 \mathrm{MHz}, \mathrm{CDCl}_{3}$ ) ppm: 7.637 (s, 1H, Ar-H), 7.601-7.425 (m, 5H, Ar-H), $7.286(\mathrm{~d}, \mathrm{~J}=8.4 \mathrm{~Hz}, 1 \mathrm{H}, \mathrm{Ar}-\mathrm{H}), 7.371(\mathrm{~d}, \mathrm{~J}=8.8 \mathrm{~Hz}$, indole $1 \mathrm{H}), 6.895(\mathrm{~d}, \mathrm{~J}=7.6 \mathrm{~Hz}$, $1 \mathrm{H}$, indole) $5.366(\mathrm{~s}, 1 \mathrm{H},=\mathrm{C}-\mathrm{H}), 1.999\left(\mathrm{~s}, 2 \mathrm{H},-\mathrm{CH}_{2}\right) .{ }^{13} \mathrm{C} \mathrm{NMR}\left(100 \mathrm{MHz}, \mathrm{CDCl}_{3}\right) \mathrm{ppm} 167.25$, $163.78,137.42,130.08,129.69,128.91,128.14,127.31,125.03,124.17,123.09,121.66$, 120.28, 112.45, 110.57, 102.76, 57.72. LC-MS (m/z): $399.07(\mathrm{M}+1)$. Molecular formula: $\mathrm{C}_{19} \mathrm{H}_{12} \mathrm{BrFN}_{2} \mathrm{O}_{2}$. Elemental analaysis: calculated: C-57.16, H-3.03, N-7.02. Obtained: C-57.11, H-3.02, N-7.09.

4-(2-Bromo-4,5-dimethoxybenzylidine)-2-((5-fluoro-1H-indolyl-1-yl)methyl)oxazol-5(4H)-one (6f). Pale red, yield $80 \%$. ${ }^{1} \mathrm{H}$ NMR (400 $\mathrm{MHz}, \mathrm{CDCl}_{3}$ ) ppm: 7.713 (s, $\left.1 \mathrm{H}, \mathrm{Ar}-\mathrm{H}\right), 7.539-7.456$ $(\mathrm{m}, 3 \mathrm{H}, \mathrm{Ar}-\mathrm{H}), 7.440(\mathrm{~d}, \mathrm{~J}=8.4 \mathrm{~Hz}, 1 \mathrm{H}, \mathrm{ArH}), 7.225(\mathrm{~d}, \mathrm{~J}=9.2 \mathrm{~Hz}$, indole $1 \mathrm{H}), 6.846(\mathrm{~d}, \mathrm{~J}=$ $7.6 \mathrm{~Hz}, 1 \mathrm{H}$, indole $) 5.825(\mathrm{~s}, 1 \mathrm{H},=\mathrm{C}-\mathrm{H}), 3.241\left(\mathrm{~s}, 6 \mathrm{H},\left(-\mathrm{OCH}_{3}\right)_{2}, 1.865\left(\mathrm{~s}, 2 \mathrm{H},-\mathrm{CH}_{2}\right) .{ }^{13} \mathrm{C} \mathrm{NMR}\right.$ $\left(100 \mathrm{MHz}, \mathrm{CDCl}_{3}\right)$ ppm: 165.89, 162.78, 136.53, 131.12, 129.33, 128.82, 127.99, 127.38, 126.46, 125.09, 123.87, 121.74, 120.02, 119.92, 113.42, 111.74, 103.88, 57.62. LC-MS (m/z): $459.19(\mathrm{M}+2)$. Molecular formula: $\mathrm{C}_{21} \mathrm{H}_{16} \mathrm{BrFN}_{2} \mathrm{O}_{4}$. Elemental analysis: calculated: C-54.92, $\mathrm{H}-$ 3.51, N-6.10. Obtained: C-54.88, H-3.49, N-6.17.

4-(2-Iodo-3,5-dimethoxybenzylidine)-2-((5-fluoro-1H-indolyl-1-yl)methyl)oxazol-5(4H)-one

(6g). Colourless, yields 81\%. ${ }^{1} \mathrm{H}$ NMR (400 MHz, $\mathrm{CDCl}_{3}$ ) ppm: 7.688 (s, 1H, Ar-H), 7.501- 
7.208 (m, 4H, Ar-H), 7.181 (d, J = 8.8 Hz, 1H, ArH), 6.817 (d, J = 8.4 Hz, 1H, Ar-H), 5.367 (s, $1 \mathrm{H},=\mathrm{C}-\mathrm{H}), 3.491\left(\mathrm{~s}, 6 \mathrm{H},\left(\mathrm{OCH}_{3}\right)_{2}\right), 1.904\left(\mathrm{~s}, 2 \mathrm{H},-\mathrm{CH}_{2}-\right) .{ }^{13} \mathrm{C} \mathrm{NMR}\left(100 \mathrm{MHz}, \mathrm{CDCl}_{3}\right) \mathrm{ppm}:$ $165.98,160.81,135.73,130.29,129.75,129.24,128.96,128.37,126.44,126.11,125.63$, 124.17, 122.77, 114.78, 111.45, 103.66, 55.27, 52.08. LC-MS (m/z): 506.43. Molecular formul: $\mathrm{C}_{21} \mathrm{H}_{16} \mathrm{FIN}_{2} \mathrm{O}_{4}$. Elemental analysis: calculated: C-49.82, H-3.19, N-5.53. Obtained: C-49.77, H$3.18, \mathrm{~N}-5.60$.

\section{Antioxidant activity}

Evaluation of antioxidant activity by DPPH radical scavenging method. The antioxidant activities of all new synthesized derivatives of 4-aryl benzelidene-2-((5-fluoro-1H-indol-1-yl) methyl)oxazol-5(4H)-one (compounds 6a-6g) have been examined by the DPPH radical scavenging effect. Free radical scavenging activity of different chemical compounds was evaluated. In brief, $0.1 \mathrm{mM}$ solution of DPPH in ethanol was prepared. This solution $(1 \mathrm{~mL})$ was added to $3 \mathrm{~mL}$ of different compounds in ethanol at different concentration $(200,100,50$, and $25 \mu \mathrm{g} / \mathrm{mL}$ ). The mixture was shaken vigorously and allowed to stand at room temp for $30 \mathrm{~min}$. After $30 \mathrm{~min}$ in room temperature, the absorbance of each solution is measured by UV spectrophotometer at $517 \mathrm{~nm}$ by using spectrophotometer (UV-VIS Shimadzu). Ascorbic acid was used as reference standard for newly synthesised compound and experiment was carried out in triplicate. Lower absorbance of the reaction mixture indicated higher free radical activity. The percentage of DPPH scavenging effect was calculated by using following equation: DPPH scavenging effect $(\%)$ or $\%$ inhibition $=\left[\left(\mathrm{A}_{0}-\mathrm{A}_{1}\right) / \mathrm{A}_{0}\right] \times 100$, where $\mathrm{A}_{0}$ was the absorbance of control reaction and $\mathrm{A} 1$ was the absorbance in presence of test or standard sample.

Table 1. Percentage of inhibition samples in difference concentrations.

\begin{tabular}{|c|c|c|c|c|c|c|c|c|}
\hline $\begin{array}{c}\text { Concentrat- } \\
\text { ion }(\mu \mathrm{g} / \mathrm{mL})\end{array}$ & $\begin{array}{c}\text { Ascorbic } \\
\text { acid }\end{array}$ & $\mathbf{6 a}$ & $\mathbf{6 b}$ & $\mathbf{6 c}$ & $\mathbf{6 d}$ & $\mathbf{6 e}$ & $\mathbf{6 f}$ & $\mathbf{6 g}$ \\
\hline 200 & $86.62 \pm 1.09$ & $30.86 \pm 1.39$ & $18.59 \pm 0.21$ & $23.05 \pm 1.39$ & $41.26 \pm 1.33$ & $25.28 \pm 0.45$ & $22.86 \pm 0.33$ & $15.35 \pm 0.41$ \\
\hline 100 & $72.12 \pm 2.33$ & $26.02 \pm 0.89$ & $13.75 \pm 0.36$ & $17.84 \pm 1.08$ & $36.43 \pm 1.84$ & $18.96 \pm 0.45$ & $20.02 \pm 0.45$ & $12.65 \pm 0.95$ \\
\hline 50 & $59.48 \pm 0.59$ & $17.47 \pm 0.98$ & $7.43 \pm 0.02$ & $11.15 \pm 0.90$ & $26.39 \pm 1.09$ & $17.10 \pm 0.33$ & $14.47 \pm 0.89$ & $10.26 \pm 0.90$ \\
\hline 25 & $48.7 \pm 1.01$ & $8.92 \pm 0.09$ & $3.35 \pm 0.03$ & $5.58 \pm 0.09$ & $18.59 \pm 0.98$ & $10.41 \pm 0.98$ & $8.92 \pm 0.11$ & $10.35 \pm 0.76$ \\
\hline
\end{tabular}

Antibacterial sensitivity assay

All the derivatives of 4-aryl benzelidene-2-((5-fluoro-1H-indol-1-yl)methyl)oxazol-5(4H)-one compounds were dissolved in DMSO and evaluated for their antimicrobial activities in vitro by disc diffusion method. Bacterial cultures were prepared in nutrient agar medium (NAM) and for fungal test potato dextrose agar (PDA) medium was used. $10 \mathrm{~mL}$ of distilled water was used to scrape conidia from 10 days culture and the spores were collected after filtration. The spores were resuspended in sterile distilled water and were used as inoculum. For bacterial culture plates a $100 \mu \mathrm{L}$ of the cell suspension) was used to prepare bacterial lawn. Antimicrobial tests were done by disc diffusion technique. Discs were prepared with Whatman No.1 filter paper and was impregnated with $100 \mu \mathrm{g} /$ disc of each compound and placed on the inoculated microbial plates. And all the plates were subjected to incubation at $37{ }^{\circ} \mathrm{C}$ for 24 hours for bacterial culture and 48-72 hours for fungal culture. Streptomycine was used as standard drug control and was placed in the centre of all the plates for bacterial cultures and Ketoconazole was used as standard drug control for fungal cultures. 


\section{RESULTS AND DISCUSSION}

\section{X-Ray Diffraction (XRD) study for $\mathrm{NiFe}_{2} \mathrm{O}_{4}$ nanoparticles}

The powder X-ray pattern recorded for the sample of $\mathrm{NiFe}_{2} \mathrm{O}_{4}$ is shown in Figure 1. It is consistent with the standard pattern cubic spinel structure of bulk $\mathrm{NiFe}_{2} \mathrm{O}_{4}$ JCPDS (Card No. 100325). The lattice parameter of $\mathrm{NiFe}_{2} \mathrm{O}_{4}$ is $\mathrm{a}=8.339 \AA$, which is close to the one reported in the previous literature [25]. Extra reflections are not detected in the X-ray diffraction pattern. The calculated average crystallite size, D is $7.3 \pm 1.2 \mathrm{~nm}$. Using Scherer's equation (1):

$\mathrm{D}=\mathrm{k} \lambda / \beta \cos \theta$

where $\mathrm{D}$ is the crystallite size, $\mathrm{k}=0.9$ is a correction factor to account for particle shapes, $\mathrm{b}$ is the full width at half maximum peaks of all planes in the XRD pattern, $\lambda$ is the wavelength of $\mathrm{Cu}$ target $=1.5406 \AA$, and $\theta$ is the Bragg angle.

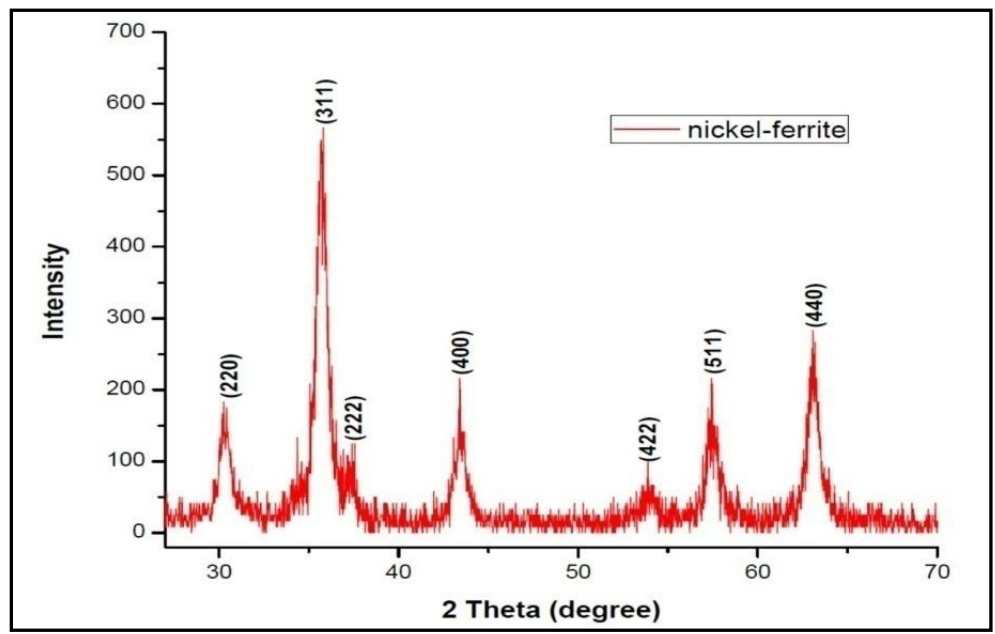

Figure 1. X-Ray diffraction pattern of $\mathrm{NiFe}_{2} \mathrm{O}_{4}$ nanoparticles.

Fourier-transform infrared spectroscopy (FTIR) study for $\mathrm{NiFe}_{2} \mathrm{O}_{4}$ nanoparticles

The FT-IR spectrum was observed the frequency range of $4000-500 \mathrm{~cm}^{-1}$. The band located at $3401 \mathrm{~cm}^{-1}$ could be attributed to the symmetric vibration of $-\mathrm{OH}$ groups. The two main metaloxygen bands at $672 \mathrm{~cm}^{-1}$ and $553 \mathrm{~cm}^{-1}$ are observed in the FT-IR spectrum of the synthesized $\mathrm{NiFe}_{2} \mathrm{O}_{4}$ samples. These two bands are usually assigned to vibration of ions in the crystal lattices. At $1362 \mathrm{~cm}^{-1}$ there is a significant change in the irrelevant peak of $-\mathrm{CH}$ bending band. The $1317 \mathrm{~cm}^{-1}$ peak is attributed to the characteristic $-\mathrm{CH}_{3}$ bending.

\section{Field emission scanning electron microscope (FESEM) analysis of $\mathrm{NiFe}_{2} \mathrm{O}_{4}$ nanoparticles}

FESEM of $\mathrm{NiFe}_{2} \mathrm{O}_{4}$ nanocomposite is shown in Figure 2. These results show the development of $\mathrm{Ni}$ on iron oxide matrix. SEM micrograph depicts that the samples contain micrometrical aggregation of tiny particles. The existence of high dense agglomeration indicates that pore free crystallites are present on the surface. The FESEM images show the agglomerated form of $\mathrm{NiFe}_{2} \mathrm{O}_{4}$ nanoparticles at 500 magnification level. As the nanoparticles possess high surface energies, they tend to agglomerate and grow into larger assemblies. 


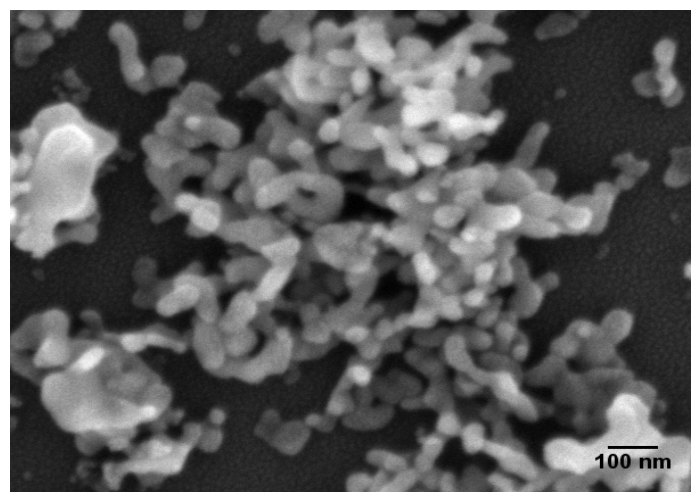

Figure 2. Field emission scanning electron microscope image of $\mathrm{NiFe}_{2} \mathrm{O}_{4}$ nanoparticles.

\section{High-resolution transmission electron microscopy (HRTEM) analysis of $\mathrm{NiFe}_{2} \mathrm{O}_{4}$ nanocomposite}

Figure 3(a,b) shows the TEM images at 500 magnification level and corresponding size distribution histogram of $\mathrm{NiFe}_{2} \mathrm{O}_{4}$ nanoparticles. The average particle size calculated was $6 \pm 0.5$ $\mathrm{nm}$ using Image-J software.

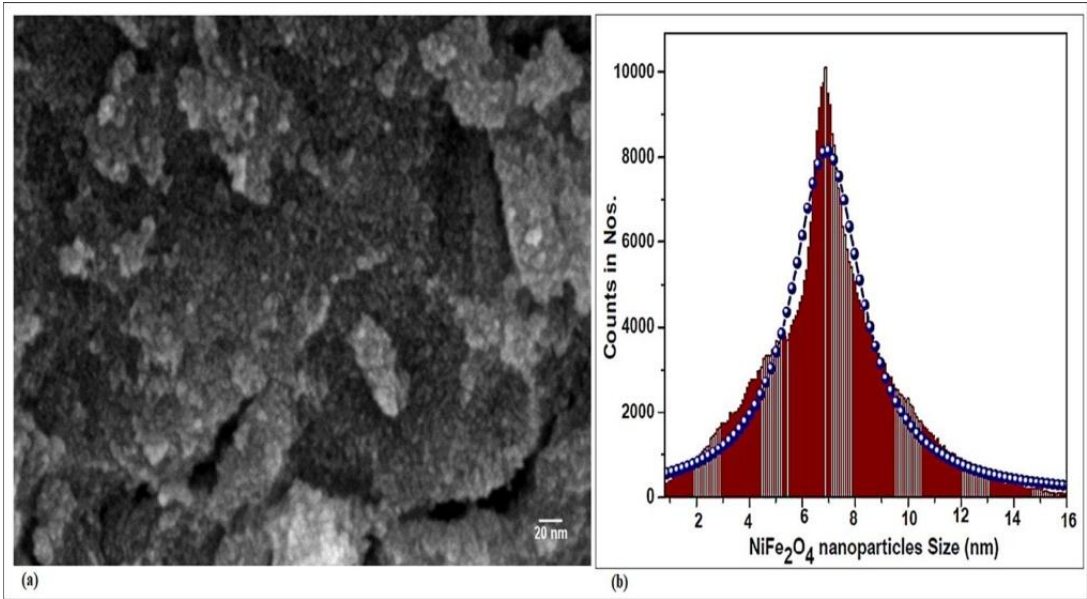

Figure 3. (a) High-resolution transmission electron microscopy image of $\mathrm{NiFe}_{2} \mathrm{O}_{4}$ nanoparticles and (b) particle size distribution curve.

\section{Chemistry}

All derivatives of 4-aryl benzelidene-2-((5-fluoro-1H-indol-1-yl)methyl)oxazol-5(4H)-one derivatives were synthesized by the condensation of substituted aromatic aldehydes with 2-(2(5-fluoro-1H-indol-1-yl)acetoamide) acetic acid, using nickel ferrite nano catalyst as a catalyst (Figure 4). All the titled compounds were evaluated different spectroscopic techniques. The ${ }^{1} \mathrm{H}-$ NMR spectrum showed characteristic pattern of peaks. The methoxy protons appeared in the region of $3.428 \mathrm{ppm}$, whereas the aromatic protons appeared at $6.89-8.10 \mathrm{ppm}$. The electron ionization mass spectrometric fragmentation patterns of the compounds were the same. The 
yield of the compounds varies from the electron donating as well as electron withdrawing groups and halogen substituted. Compounds having disubstituted electrondonating groups (6g and $\mathbf{6 f})$ and also got more yields compare the monosubstituted electrondonating groups $(\mathbf{6 b}, \mathbf{6 c}$ and $\mathbf{6 d}$ ). All the newly titled synthesized compounds can be synthesized under reflux condition. These target compounds can be obtained, we used to nickel nano catalyst. This catalyst can be used to improve the reaction conditions and reaction is completed maximum 2 hours. The rate of reaction increased by using this catalyst. We used various substituted aryl aldehydes such as electron donating group of aldehydes and electron withdrawing group of aldehydes and halogen containing aldehydes.

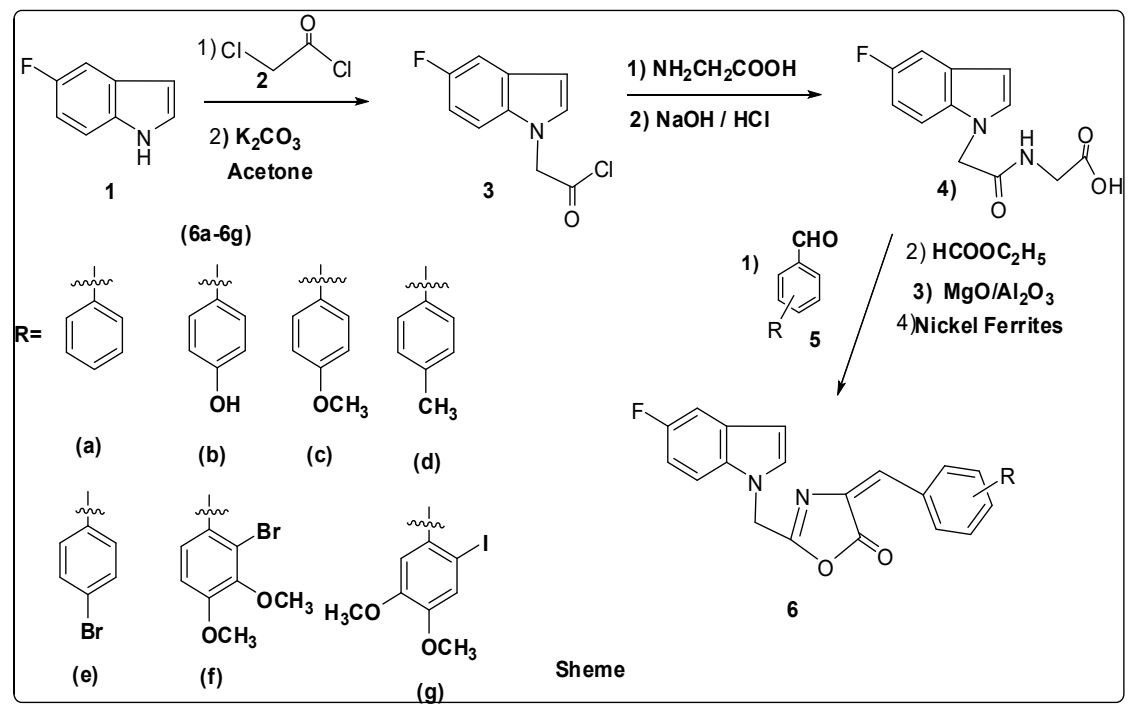

Figure 4. The schematic illustration of chemical reactions of 4-aryl benzelidene-2-((5-fluoro- $1 \mathrm{H}-$ indol-1-yl) methyl)oxazol-5(4H)-one.

Antioxidant activity

An Antioxidant activities of the all derivatives of 4-aryl benzelidene-2-((5-fluoro-1H-indol-1-yl) methyl)oxazol-5(4H)-one (compounds 6a-6g) were measured using the DPPH radical scavenging method. The observed antioxidant properties derivatives of 4-aryl benzelidene-2-( $(5-$ fluoro-1H-indol-1-yl)methyl)oxazol-5(4H)-one in Table 2. From the Table 2, the hydroxy- and methoxy-substituted compounds (6b and $\mathbf{6 c}$ ) showed significant antioxidant activity. The other including the parent compound showed lesser antioxidant activity.

\section{Anti bacterial activity}

The anti bacterial activities of newly synthesized derivatives of 4-aryl benzelidene-2-((5-fluoro1H-indol-1-yl)methyl)oxazol-5(4H)-one compounds are examined against four pathogenic bacteria strains. The result of antibiotic activity studies for these compounds. The gram negative bacteria screened were Escerichia coli and $S$. aureus. The gram positive bacteria screened were S. typhi and Bacillus. The target compounds were used at the concentration of $250 \mu \mathrm{g} / \mathrm{mL}$ and $500 \mu \mathrm{g} / \mathrm{mL}$ using DMSO as a solvent the streptomycine $25 \mu \mathrm{g} / \mathrm{mL}$ disc were used as a standard. The rest of the compounds were found to be moderate active against the tested micro organism. 


\section{Anti fungal activity}

Anti fungal activity of new synthesized derivatives of 4-aryl benzelidene-2-((5-fluoro-1H-indol1-yl)methyl)oxazol-5(4H)-one compounds are examined by disc diffusion method against the organism of Aspergillus niger and Candida ablicans. Compared were treated at the concentrations of $250 \mu \mathrm{g} / \mathrm{mL}$ and $500 \mu \mathrm{g} / \mathrm{mL}$ using DMSO as a solvent. The standard drug was used as ketoconazol $22 \mu \mathrm{g} / \mathrm{mL}$ against both organisms.

All the synthesized derivatives of 4-aryl benzelidene-2-((5-fluoro-1H-indol-1-yl) methyl) oxazol-5(4H)-one compounds were examined anti bacterial activity as well as antifungal. The electron withdrawing groups of compounds show low activities. On the other hand electron withdrawing group of compounds exhibited poor activity compared with electron donating groups. All halogen compounds exhibit moderate activity. The compound which possess electron donating group shows excellent activity as shown in Table 2.

Table 2 . Antimicrobial activity screening activity synthesized scaffold.

\begin{tabular}{|c|c|c|c|c|c|c|}
\hline \multirow{3}{*}{ Compound } & \multicolumn{6}{|c|}{ Zone of inhibition in (mm) } \\
\hline & \multicolumn{4}{|c|}{ Bacteria } & \multicolumn{2}{|c|}{ Fungi } \\
\hline & S.aureus & E.coli & S. typhi & B.substills & A. niger & C. albicans \\
\hline $8 \mathbf{8}$ & 10 & 10 & 06 & 04 & 09 & 07 \\
\hline $8 b$ & 22 & 20 & 17 & 18 & 15 & 14 \\
\hline $8 c$ & 19 & 18 & 15 & 16 & 10 & 11 \\
\hline $8 d$ & 15 & 17 & 09 & 15 & 20 & 19 \\
\hline $8 e$ & 16 & 10 & 11 & 13 & 09 & 07 \\
\hline $8 f$ & 21 & 19 & 20 & 19 & 16 & 17 \\
\hline $8 g$ & 22 & 20 & 19 & 22 & 19 & 18 \\
\hline Streptomycine & 25 & 25 & 25 & 25 & NA & NA \\
\hline Ketoconazole & NA & NA & NA & NA & 22 & 22 \\
\hline DMSO & --- & ---- & --- & --- & --- & --- \\
\hline
\end{tabular}

\section{CONCLUSION}

The reaction condition carried at reflux for all the newly synthesised compounds . The yield of the titled compounds obtained from $86-93 \%$. The compound possesses electron donating group gives maximum yeild than that of the compound possesses electron withdrawing group. The rate of reaction developed by using nano catalyst.All the compounds tested by anti microbial activity against gram positive ,gram negitive and fungal.The compound having electron donating group showed excelent active potential .Other8 wise the compounds having halogens which showed better active potential than that of the electron with drwing group.

\section{REFERENCES}

1. Rawan, N.A. The implications and applications of nanotechnology in dentistry: A review. Saudi Dent. J. 2018, 30, 107-116.

2. Huseyin, K.; Nermin, K.; Abdulhadi, B.; Yuksel, K. Characterization of $\mathrm{NiFe}_{2} \mathrm{O}_{4}$ nanoparticles synthesized by various methods. Chem. Papers 2009, 63, 450-455.

3. Mouallem-Bahout, M.; Bertrand, S.; Pe'na, O. Synthesis and characterization of $\mathrm{Zn}^{1-\mathrm{x}} \mathrm{NixFe}_{2} \mathrm{O}_{4}$ spinels prepared by a citrate precursor. J. Solid State Chem. 2005, 178, 10801086.

4. Maaz, K.; Karim, S.; Mumtaz, A; Hasanain, S.K; Liu, K.; Duan, J.L. Synthesis and magnetic characterization of nickel ferrite nanoparticles prepared by co-precipitation route. J. Magn. Magn. Mater. 2009, 321, 1838-1842.

5. Aaglawe, M.J.; Dhule, S.S.; Bahekar, S.S.; Wakte, P.S.; Shinde, D.B. Synthesis and antibacterial activity of some oxazolone derivatives. J. Korean Chem. Soc. 2003, 47, $133-$ 136. 
6. Palcut, M. Spectral properties of novel 1,3-oxazol-5(4H)-ones with substituted benzylidene and phenyl rings. Acta Chim. Slovenica 2009, 56, 362-368.

7. Matsunaga, H.; Ishizuka, T.; Kunieda, T. Synthetic utility of five-membered heterocycleschiral functionalization and applications. Tetrahedron 2005, 61, 8073-8094.

8. Ellaithy, M.M.; El-Ragehy, N.A.; ElGhobashy, M.A. Kinetic study of alkaline induced hydrolysis of the skeletal muscle relaxant chlorzoxazone using ratio spectra first derivative Spectrophotometry. IL Farmaco 2003, 58, 337-342.

9. Pasha, M.A.; Jayashankara, V.P.; Venugopala, K.N.; Rao, G.K. Zinc oxide (ZnO): An efficient catalyst for the synthesis of 4-arylmethylidene-2-phenyl-5-(4H)-oxazolones having antimicrobial activity. J. Pharmacol. Toxicol. 2007, 2, 264-270.

10. Siddiqui, S.A.; Bhusare, S.R.; Jarikote, D.V.; Pawar, R.P.; Vibhute, Y.B. New novel synthesis and antibacterial activity of 1-(substituted phenyl)-2-phenyl-4-(3'-halo,4'-hydroxy 5'-methoxy benzylidene)-imidazole-5-ones. Bull. Korean Chem. Soc. 2001, 22, 1033-1036.

11. Desai, N.C.; Bhavsar, A.M.; Baldaniya, B.B. Synthesis and antimicrobial activity of 6imidazolinone derivatives. Indian J. Pharm. Sci. 2009, 71, 90-94.

12. Abdel-Aty, A.S.; Pesticidal effects of some imidazolidine and oxazolone derivatives. World J. Agric. Sci. 2009, 5, 105-113.

13. Argade, N.D.; Kalrale, B.K.; Gill, C.H. Microwave assisted improved method for the synthesis of pyrazole containing 2,4-disubstitute oxazole-5-one and their antimicrobial activity. Eur. J. Chem. 2008, 5, 120-129.

14. Sanchez, C.; Mendez, C.; Salas, J.A. Indolocarbazole natural products: Occurrence, biosynthesis and biological activity. Nat. Prod. Rep. 2006, 23, 1007-1045.

15. Madkour, H.M.F. Simple one-step syntheses of heterocyclic systems from (4Z)-2-phenyl-4(thien-2-ylmethylene)-1,3(4H)-oxazol-5-one. Chem. Papers 2002, 56, 313-319.

16. Khan, K.M.; Mughal, U.R.; Khan, M.T.H.; Ullah, Z.; Perveen, S.; Choudhary, M.I.; Oxazolones: New tyrosinase inhibitors; synthesis and their structure-activity relationships. Bioorg. Med. Chem. 2006, 14, 6027-6033.

17. Tikdari, A.M.; Fozooni, S.; Hamidian, H. Dodecatungstophosphoric acid $\left(\mathrm{H}_{3} \mathrm{PW}_{12} \mathrm{O}_{40}\right)$, samarium and ruthenium (iii) chloride catalyzed synthesis of unsaturated 2-phenyl-5(4H)oxazolone derivatives under solvent-free conditions. Molecules 2008, 13, 3246-3252.

18. Bourotte, M.; Schmitt, M.; Wund, A.F.; Pigault, C.; Haiech, J.; Bourguignon, J.J. Fluorophores related to the green fluorescent protein. Tetrahedron Lett. 2004, 45, 6343-6348.

19. Altherr, W.; Linden, A.; Heimgartner, H. The 'azirine/oxazolone method' in peptaibol synthesis: Preparation of a derivative of trichotoxin A-50 (G). Chem. Biodiver.. 2007, 4, 1144-1169.

20. Kottgen, P.; Linden, A.; Heimgartner, H. Synthesis of a regular 24-membered cyclodepsipeptide by direct amide cyclization. J. Chem. Sci. 2009, 64b, 689-698.

21. Fazary, A.E.; Metal complexes of salicylhydroxamic acid and 1,10-phen-anthroline; equilibrium and antimicrobial activity studies. Bull. Chem. Soc. Ethiop. 2014, 28, 393-402.

22. Rao, N.K.; Rao, T.N.; Parvatamma, B.; Devi, K.P.; Setty, S.C. Multi component one pot synthesis and characterization of derivatives of 2-amino-7,7-dimethyl-5-oxo-4-phenyl5,6,7,8-tetrahydro-4H-chromene-3-carbonitrile and study of anti-microbial activity. Bull. Chem. Soc. Ethiop. 2018, 32, 133-138.

23. Onar, H.C.;Vardar, B.A. Synthesis and antioxidant activity of novel 8-formyl-4-substitued coumarins. Bull. Chem. Soc. Ethiop. 2018, 32, 175-178.

24. Krishna Rao, N.; Surendra Babu, M.S.; Basaveswara Rao. M.V.; Nageswara Rao, T.; Apparao, K. A novel synthesis and characterization of 1,2,3,4-tetrahydropyrimidin-2(1H)thiones. Asian J. Chem. 2017, 29, 882-884.

25. Nermin, K.; Abdulhadi, B.; Muhammet, S.T.; Yuksel, K.; Harun, B. Synthesis and characterization of $\mathrm{NiFe}_{2} \mathrm{O}_{4}$ nano-octahedrons by EDTA-assisted hydrothermal method. Turk. J. Chem. 2007, 31, 659-666. 